\title{
In situ Localization of Specific RNAs in Whole Fruiting Colonies of Schizophyllum commune
}

\author{
By M. H. J. RUITERS† AND J. G. H. WESSELS* \\ Department of Plant Biology, Biological Centre, University of Groningen, Kerklaan 30 , \\ 9751 NN Haren, The Netherlands
}

(Received 21 October 1988; revised 15 February 1989; accepted 2 March 1989)

cDNA clones representing eight specific mRNAs abundantly expressed in a dikaryon of Schizophyllum commune but not in the progenitor monokaryons, were used to localize these mRNAs in whole colonies by in situ hybridization. A genomic clone for 18S rRNA was used to probe for rRNA. The colonies were grown on hybridization membranes, fixed, and treated with RNAase-depleted wall-lytic enzymes from Trichoderma harzianum to facilitate permeation of the probes. RNAs in sectors of the colonies were then localized with [32P]DNA probes. Hybridization at different developmental stages showed that the specific mRNAs were only formed in parts of the colony where fruit-body initials arose. At later stages these mRNAs disappeared from abortive fruit bodies but remained high in fruit bodies continuing development.

\section{INTRODUCTION}

Mating of two co-isogenic monokaryotic strains of Schizophyllum commune differing only in the alleles of the two incompatibility genes $A$ and $B$ generates a dikaryon with a genome identical to that of the mates except for the differences in the alleles of the incompatibility genes. The interactions between the different incompatibility alleles causes the hyphal morphology to switch from a monokaryotic type with mononucleated cells to a dikaryotic type with binucleate cells and clamp connections and also prompts the formation of fruit bodies under appropriate environmental conditions (Wessels, 1987). In the dikaryon some specific mRNAs accumulate at high concentrations, temporally and spatially correlated with fruit-body development (Mulder \& Wessels, 1986; Wessels et al., 1987; Ruiters et al., 1988).

In the present paper we describe an in situ hybridization method developed for the detection of these mRNAs in whole colonies of $S$. commune. Compared to mRNA determinations in RNA extracted from concentric rings of a colony (Ruiters et al., 1988), this method gives a more detailed picture of the spatial distribution of the mRNAs in the colony during development.

\section{METHODS}

Organism and culture conditions. A dikaryon of Schizophyllum commune constituted by mating strains 4-39 (CBS 341.81, ATCC 44200, A41B41) and 4-40 (CBS 341.80, ATCC 44201, A43B43) was used throughout. The growth substrate was complete medium (Raper \& Hoffman, 1974) solidified with $1.5 \%$ (w/v) agar. To obtain colonies suitable for in situ hybridization the fungus was inoculated on membranes which were deposited on $25 \mathrm{ml}$ agar medium in $9 \mathrm{~cm}$ Petri dishes. Various membranes were tried. Water-permeable cellophane was unsuitable because colonies detached from the membrane after fixation. Cellulose nitrate membranes (BA 85, Schleicher and Schuell) and cellulose acetate membranes (pore sizes 0.45 and $8 \mu \mathrm{m}$, Millipore) reduced the linear growth rate of the colonies by $20-40 \%$. Genescreen membranes (NEN) proved satisfactory giving firm attachment of the colony and an only slightly reduced growth rate. The fungus grew through the membrane and to prevent it from growing

† Present address: Department of Physiological Chemistry, University of Groningen, Bloemsingel 10,9712 KZ Groningen, The Netherlands. 
into the agar a cellophane membrane was positioned between the agar and the Genescreen membrane. The cultures were grown in a circulating-air incubator at $24^{\circ} \mathrm{C}$ and $95 \%$ relative humidity. Dark conditions were obtained in a light-proof box standing in this incubator. Air from the incubator was pumped through the box to maintain the same atmospheric conditions in the box as in the incubator. It was essential to keep the relative humidity at about $95 \%$ during growth to maintain medium contact between the membranes and the nutrient agar. The colonies were first grown in darkness at $24^{\circ} \mathrm{C}$ for $5 \mathrm{~d}$ (colony diameter $20-25 \mathrm{~mm}$ ) and then transferred to light $(1000 \mathrm{~lx})$ to induce the formation of fruit bodies. Within $2 \mathrm{~d}$ fruit bodies were seen macroscopically in a ring at the position representing the border of the colony at the moment of the switch to light.

Cell-wall degrading enzymes. Cell-wall degrading enzymes were isolated from the culture fluid of Trichoderma harzianum (CBS 354.33) as described by De Vries \& Wessels (1972) but with Penicillium chrysogenum wall residues as a substrate (Sonnenberg \& Wessels, 1987). This enzyme preparation showed considerable RNAase activity: incubating $200 \mu \mathrm{g}$ total RNA of $S$. commune with $100 \mu \mathrm{g}$ wall-lytic enzymes in $0.5 \mathrm{ml} 10 \mathrm{~mm}$-sodium acetate buffer, pH 6.0, at $37^{\circ} \mathrm{C}$ for $1 \mathrm{~h}$ converted $43.5 \%$ of the RNA into perchloric-acid-soluble products. To remove this RNAase activity, the enzyme powder was dissolved $\left(2 \mathrm{mg} \mathrm{m}^{-1}\right)$ in $10 \mathrm{~mm}$-sodium acetate, $\mathrm{pH} 6.0$ and mixed with an equal volume of $2 \%(\mathrm{w} / \mathrm{v})$ bentonite in $10 \mathrm{~mm}$-sodium acetate, $\mathrm{pH} 6.0$. This suspension was left at room temperature for $2 \mathrm{~h}$ with occasional shaking. After centrifugation $(5 \mathrm{~min}, 10000 \mathrm{~g})$ the supernatant with no detectable RNAase activity was used immediately or stored at $-30^{\circ} \mathrm{C}$.

Hybridization probes. The probes were cDNA sequences cloned in pGEM-1 (Promega Biotec) representing mRNAs specifically present in fruiting dikaryons (Sc-1, $-2,-4,-5,-6,-7,-9$, and -14) and one mRNA (Sc-3) present in both monokaryotic and dikaryotic mycelium (Mulder \& Wessels, 1986). A 1.8 kbp EcoRI/XbaI genomic clone containing a part of the $18 \mathrm{~S}$ ribosomal RNA gene of $S$. commune was isolated (Ruiters \& Wessels, 1989) and used as a probe for rRNA. The vector pGEM-1 was used as a control.

Labelling of the plasmid. Plasmid DNA was labelled by nick-translation with $\left[\alpha^{-32} \mathrm{P}\right] \mathrm{dCTP}$ as described by Meinkoth \& Wahl (1984) with a slight modification according to Mulder \& Wessels (1986). Specific activity was about $5 \times 10^{7}$ d.p.m. $\mu \mathrm{g}^{-1}$.

In situ hybridization of colonies. Cultures at various developmental stages were fixed by pouring $15 \mathrm{ml} 4 \%$ paraformaldehyde in PBS (phosphate-buffered saline: $137 \mathrm{~mm}-\mathrm{NaCl}, 1.5 \mathrm{~mm}-\mathrm{KH}_{2} \mathrm{PO}_{4}, 7 \mathrm{~mm}-\mathrm{Na}_{2} \mathrm{HPO}_{4}, 7 \mathrm{~mm}$ $\mathrm{KCl}$, pH 7.4) on the membrane-grown colony in a Petri dish. To improve penetration of the fixative a vacuum was applied for $15 \mathrm{~min}$ and fixation was continued for another $15 \mathrm{~min}$ at ambient pressure. The membrane with adhering colony was lifted off the cellophane-covered agar plate, washed three times in PBS (5 min) after which the membrane was blocked off with $3 \% \mathrm{BSA}$ in PBS for $4 \mathrm{~h}$ at $65^{\circ} \mathrm{C}$. (This was necessary because omission of this step caused binding of wall-degrading enzymes to the membrane in the next step, preventing adequate permeabilization of the walls.) The filter was then washed in $10 \mathrm{~mm}$-sodium acetate, pH 6.0, for $5 \mathrm{~min}$. Treatment with cell-wall degrading enzymes $\left(1 \mathrm{mg} \mathrm{ml}^{-1}\right.$ in $10 \mathrm{mM}$-sodium acetate, $\left.\mathrm{pH} 6.0\right)$ proceeded overnight $(16-18 \mathrm{~h})$ at $37^{\circ} \mathrm{C}$. The membrane was washed twice $(5 \mathrm{~min})$ in PBS and again blocked off with $3 \% \mathrm{BSA}$ in PBS at $65^{\circ} \mathrm{C}$ for $1 \mathrm{~h}$. (This second blocking treatment was necessary to prevent all background absorption of probes.) The membrane with colony was then cut into $30^{\circ}$ sectors which were marked. Four filter sectors to be hybridized with one specific probe were sealed in one polyethylene bag containing $5 \mathrm{ml}$ pre-hybridization buffer, $\mathrm{pH} 8.0(50 \%, \mathrm{v} / \mathrm{v}$, formamide; $0.3 \mathrm{M}-\mathrm{NaCl} ; 10 \mathrm{~mm}$-Tris; $1 \mathrm{~mm}$-EDTA; $1 \% \mathrm{SDS}$ and $100 \mu \mathrm{g}$ herring sperm DNA $\mathrm{ml}^{-1}$ ). Prehybridization was done at $42^{\circ} \mathrm{C}$ for $2 \mathrm{~h}$. Hybridization was then done at $42^{\circ} \mathrm{C}$ for at least $16 \mathrm{~h}$ in the same solution after adding $10 \mathrm{ng}$ of ${ }^{32} \mathrm{P}$-labelled probe per $\mathrm{ml}$ of hybridization buffer. Before addition, the probe was boiled for $3 \mathrm{~min}$ and cooled on ice. After hybridization the filters were washed in $2 \times \mathrm{SSC}(1 \times \mathrm{SSC}$ is $0 \cdot 15 \mathrm{M}-\mathrm{NaCl}, 15 \mathrm{mM}-$ sodium citrate, $\mathrm{pH} \mathrm{7.0)}$ ) plus $0.1 \% \mathrm{SDS}$, twice for $5 \mathrm{~min}$ at room temperature and twice for $30 \mathrm{~min}$ at $65^{\circ} \mathrm{C}$. The hybridized filters were then positioned so as to image the original colony and exposed to Kodak XAR-5 film for an appropriate time at $-70^{\circ} \mathrm{C}$ using one intensifying screen.

For re-hybridization of the filters with the $18 \mathrm{~S}$ rDNA clone, hybridized filters were stored at $-70^{\circ} \mathrm{C}$ for 4 weeks (twice the half-life of the ${ }^{32} \mathrm{P}$ label). Re-hybridization was then started at the pre-hybridization step in the protocol given above.

Scanning profiles of whole colony hybridizations. After hybridization of the membrane colonies with the specific cDNA clones and recording the results on X-ray film, the colonies were stored for 4 weeks at $-70{ }^{\circ} \mathrm{C}$ to lower their radioactivity, and then rehybridized with the $18 \mathrm{~S}$ rDNA clone. The X-ray film recordings of the two hybridizations were scanned with a Joyce Loebl microdensitometer along three different radii for each mRNA hybridization and along corresponding radii for the rRNA re-hybridization. The signals were averaged and corrected for differences in exposure time and specific activities of the probes. The ratio of the corrected signals, i.e. the relative abundances of the mRNAs, was then plotted along the radius of the colony.

\section{RESULTS}

\section{In situ hybridization of RNA in colonies}

Fig. $1(a)$ shows a $90^{\circ}$ sector of a 5-d-old dark-grown colony of $S$. commune hybridized to the $18 \mathrm{~S}$ rDNA clone according to the protocol outlined in Methods but without the treatment with 


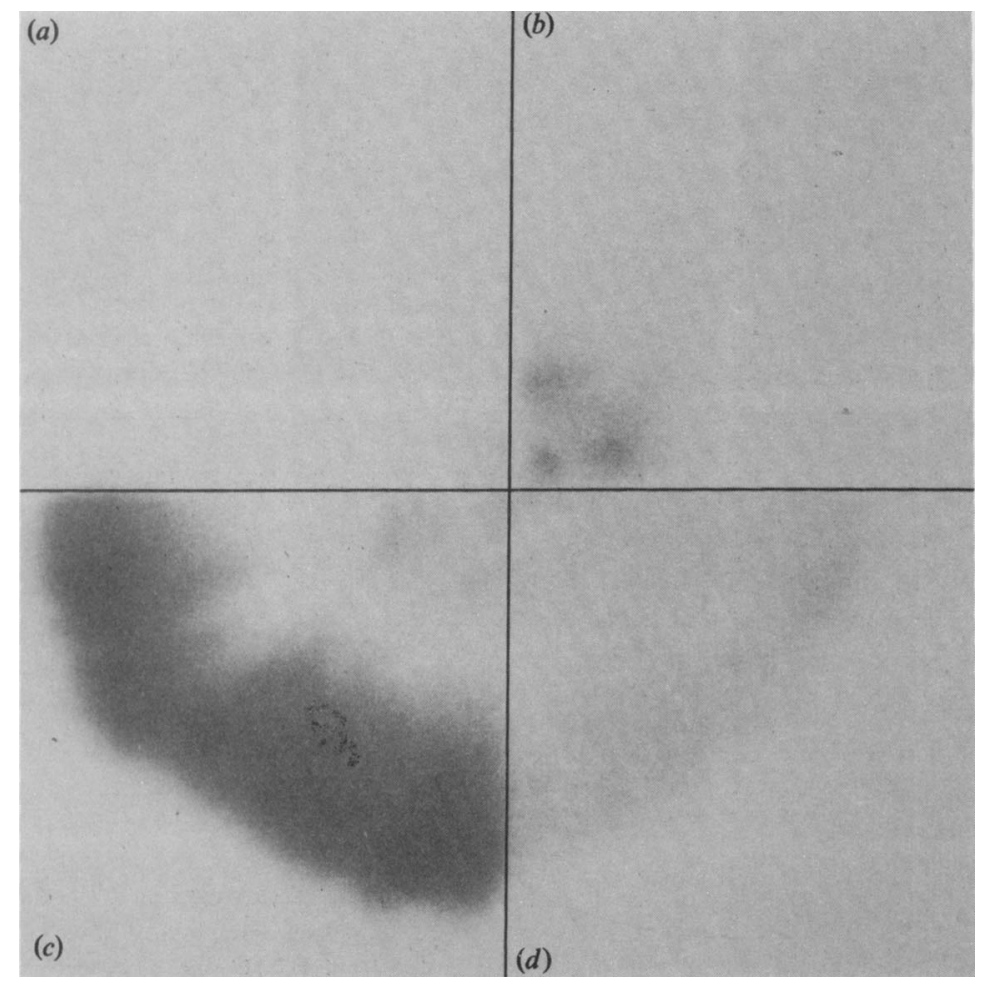

Fig. 1. Autoradiographs of sectors from a 5-d-old dark-grown culture of $S$. commune on a Genescreen membrane hybridized to an $18 \mathrm{~S}$ rDNA clone. (a) Not treated with wall-lytic enzymes; $(b)$ pretreated with crude cell-wall lytic enzymes; $(c$ and $d)$ pretreated with RNAase free cell-wall lytic enzymes but $(d)$ additionally treated with RNAase. Exposure time, $4 \mathrm{~d}$.

wall-lytic enzymes. No hybridization signal is visible. Inclusion of a treatment with a nonpurified wall-lytic enzyme preparation resulted in a weak hybridization signal near the inoculum (Fig. 1 b) . A strong hybridization signal, particularly at the growing edge of the colony, was present in a sector incubated with a bentonite-treated enzyme preparation (Fig. $1 c$ ). When a sector incubated with this RNAase-free wall-lytic enzyme preparation was subsequently treated with $2 \mathrm{mg} \mathrm{ml}^{-1}$ RNAase $A$ and $600 \mathrm{U} \mathrm{ml}^{-1}$ RNAase $\mathrm{T}_{1}$ at $37^{\circ} \mathrm{C}$ for $2 \mathrm{~h}$, a very weak hybridization signal was obtained (Fig. $1 d$ ). In none of these treatments was a hybridization signal seen when the vector pGEM-1 without insert was used as a probe (not shown). These results show that permeabilization of the walls prior to hybridization was necessary and that the signal was derived from an RNA specific to the probe.

\section{Localization of RNAs during fruit-body development}

${ }^{32} \mathrm{P}$-Labelled DNA probes for the various mRNAs known to be elevated in the dikaryon at the time and place of fruiting (Mulder \& Wessels, 1986; Ruiters et al., 1988) were used to estimate local concentrations of these RNAs in sectors of whole colonies induced for fruit-body development.

Fig. 2 shows the results of in situ hybridization at five developmental stages. At the moment of transfer of a 5-d-old dark-grown colony to the light to induce fruit bodies none of the probed mRNAs was visible (Fig. $2 b, 0 \mathrm{~h}$ ), although prolonged exposure showed the presence of low concentrations of mRNAs Sc-3 and Sc-4 throughout the colony (not shown). After $12 \mathrm{~h}$ of illumination $\mathrm{Sc}-4$ and $\mathrm{Sc}-3$ were located at a position representing the colony edge at the moment of transfer to the light (Fig. $2 b, 12 \mathrm{~h}$ ), where fruit-body development started (microscopic aggregates, not shown). Macroscopically, a fruit-body ring was clearly distinguishable after $24 \mathrm{~h}$ (Fig. $2 a, 24 \mathrm{~h}$ ) and all fruiting-associated mRNAs were elevated in the ring except Sc-14 (Fig. 
(a)

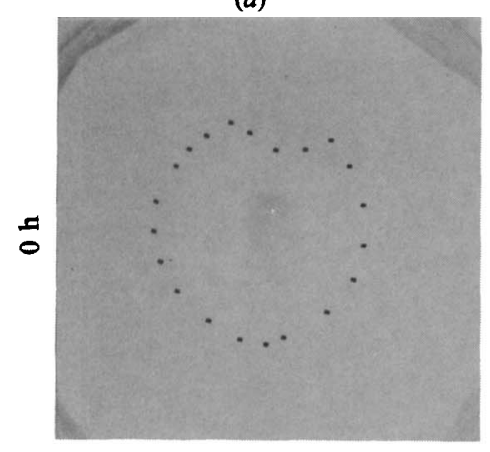

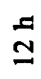

竝
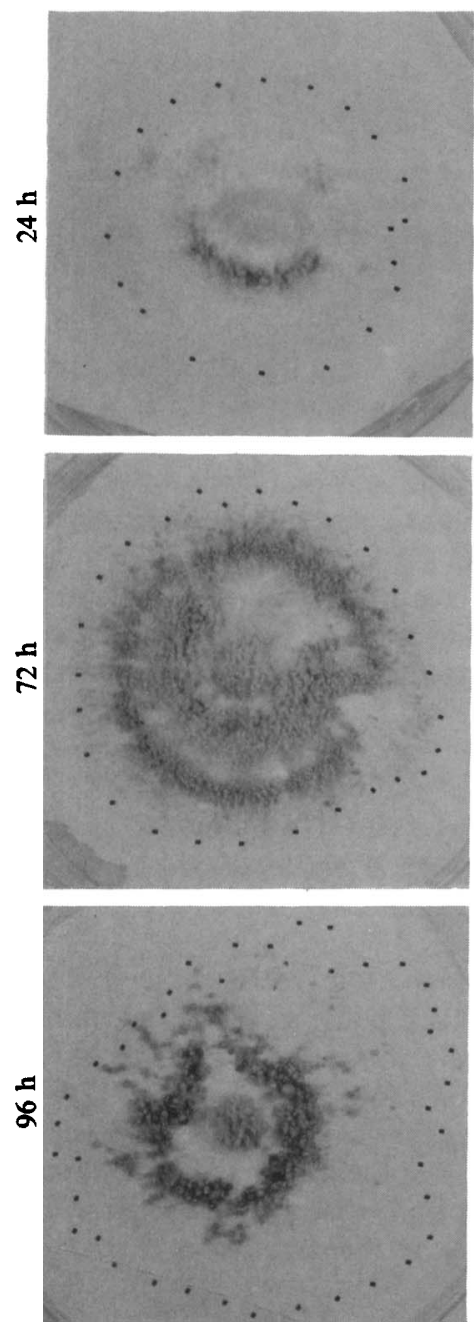

(b)
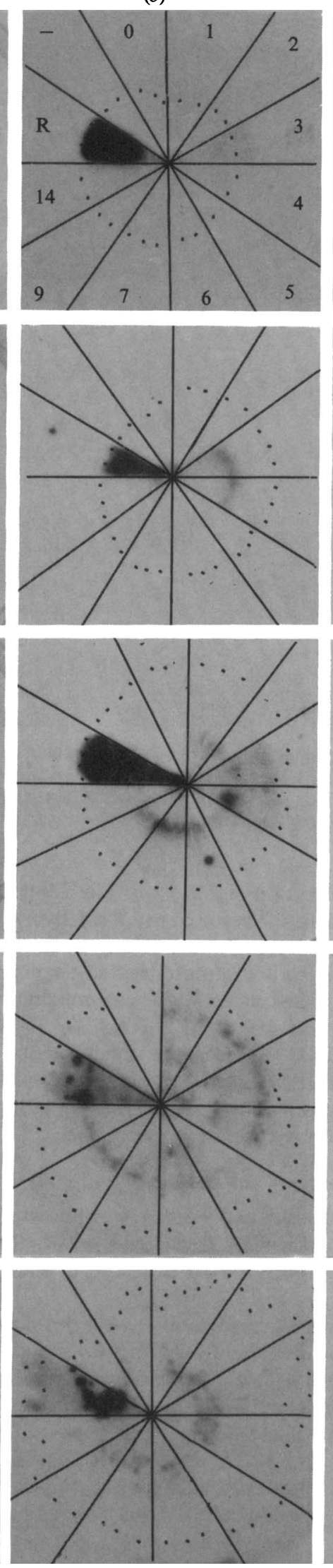

(c)
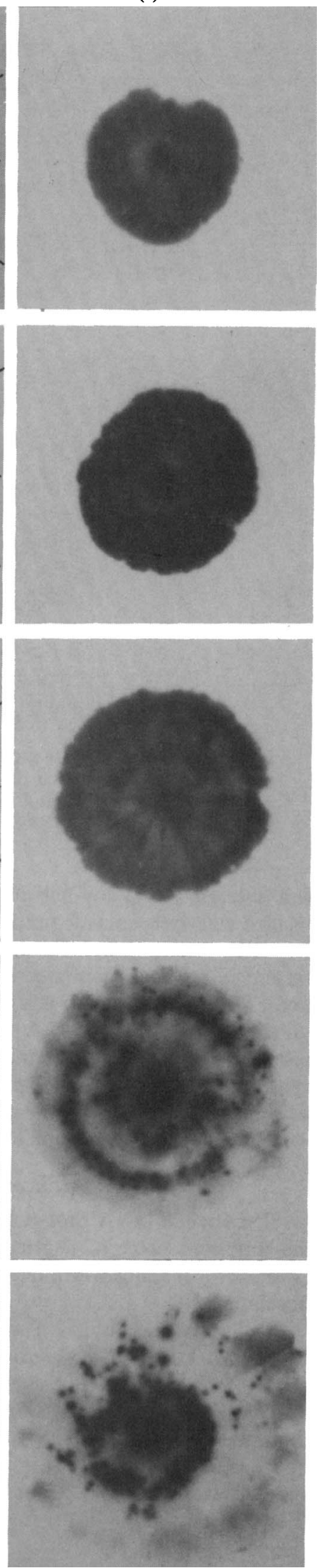
$2 b, 24 \mathrm{~h}$ ). mRNAs Sc-3 and Sc-4 also became elevated in a newly established ring of initials sometimes arising outside the original ring of primordia (Fig. $2 b, 72 \mathrm{~h}$ ). Primordia also arose at the site of the inoculum (Fig. $2 a, 72 \mathrm{~h}$ ). After $72 \mathrm{~h}$ of illumination all dikaryon-specific mRNAs were detected at places where primordia were present (Fig. $2 b, 72 \mathrm{~h}$ ). After $96 \mathrm{~h}$ of illumination some fruit bodies continued development while others became abortive. The specific mRNAs disappeared from these abortive fruit bodies (also identified by their loss of rRNA; see below) but remained high in fruit bodies continuing development.

$\mathrm{Up}$ to $24 \mathrm{~h}$ after transfer to the light $18 \mathrm{~S}$ rRNA was present throughout the colony with the highest concentration in the outer region, presumably the metabolically most active part of the colony (Fig. 1; Fig. $2 c, 0-24 \mathrm{~h}$ ). At $72 \mathrm{~h}$ after transfer, 18S rRNA became concentrated in the fruit-body primordia with a loss of hybridization signal in the vegetative mycelium (Fig. $2 c$, $72 \mathrm{~h}$ ). After $96 \mathrm{~h}$ of illumination the 18S rRNA signal was present in developing fruit bodies but absent from abortive primordia. In a representative case of 203 visible primordia only $60 \%$ showed an $18 \mathrm{~S}$ rRNA hybridization signal at this time of development.

\section{Scanning profiles of whole-colony hybridizations}

Colonies were grown for $7 \mathrm{~d}$ in darkness or for $5 \mathrm{~d}$ in darkness followed by $2 \mathrm{~d}$ in light to induce fruit bodies. After hybridizations with the specific cDNA clones and re-hybridization with the rDNA clone the ratio of the signals obtained in the two hybridization experiments were plotted along the radii of the colonies (see Methods). The pattern shown in Fig. 3 was found in three independent experiments. It appears that not only the absolute amounts (as recorded in Fig. 2) but also the relative abundances of the probed mRNA (mRNA/rRNA) were generally highest in the primordial ring induced by light and remained low in darkness. (Note that the absolute concentration of the mRNAs is not reflected in the curves; see Discussion.) mRNA Sc-9 also seemed to be elevated at the margin of the colonies, especially in dark-grown colonies. It should be noted, however, that the ratio of specific mRNA/18S rRNA at the margin becomes very imprecise because both signals fall rapidly to very low values at the low density of hyphae at the margin. Therefore, in Fig. 3, values for the extreme margin of the colonies are not given.

\section{DISCUSSION}

In situ hybridizations are mostly done on sectioned tissues exposing the cytoplasm to the nucleic acid probes, e.g. in animals (Akam, 1983; Cox et al., 1984; Hafen et al., 1987) and plants (Cornish et al., 1987; Martineau \& Taylor, 1986; Schmelzer et al., 1988; Smith et al., 1987). Whole colonies of Saccharomyces cerevisiae have been treated with Zymolase to digest the walls and then hybridized to probes to quantitate mRNA (Yu \& Gorovsky, 1986). Similar procedures have been described to detect specific DNA sequences in yeast (Blanc et al., 1987; Hinnen et al., 1978) and filamentous fungi (Crowley \& Oliver, 1987; Stohl \& Lambowitz, 1983). However, our aim was to devise a method for localization of RNAs in particular parts of a colony. We adapted a procedure previously developed for in situ hybridizations in sectioned fungal tissues which also contain intact walls posing a barrier to permeation of the probes (Ruiters \& Wessels, 1989). To permeabilize the walls we used an enzyme preparation derived from Trichoderma harzianum known to be effective in releasing protoplasts from $S$. commune and a variety of other basidiomycetes and ascomycetes (De Vries \& Wessels, 1973), a capacity only slightly reduced by treatment of the enzyme preparation with bentonite to remove RNAase (not shown). The hybridization signals were clearly due to DNA/RNA hybridization, and not to DNA/DNA

Fig. 2. In situ hybridization of 5-d-old dikaryotic colonies of Schizophyllum commune after transfer to the light. Column $(a)$, morphological appearance of the colonies at various times after transfer. The extreme margin of the colonies is indicated by stippling in columns $(a)$ and $(b)$. Column $(b)$, autoradiographs of the same colonies after hybridization of $30^{\circ}$ sectors with the specific clones for mRNAs Sc-1, $-2,-3,-4,-5,-6,-7,-9,-14$, and 18 S rRNA (R), the vector without insert (-), and a blank without DNA during hybridization (0) (exposure time $4 \mathrm{~d}$ ). Column $(c)$, autoradiographs of the same sectors shown in $(b)$ but after rehybridization with an 18S rDNA clone (exposure time $1 \mathrm{~d}$ ). 

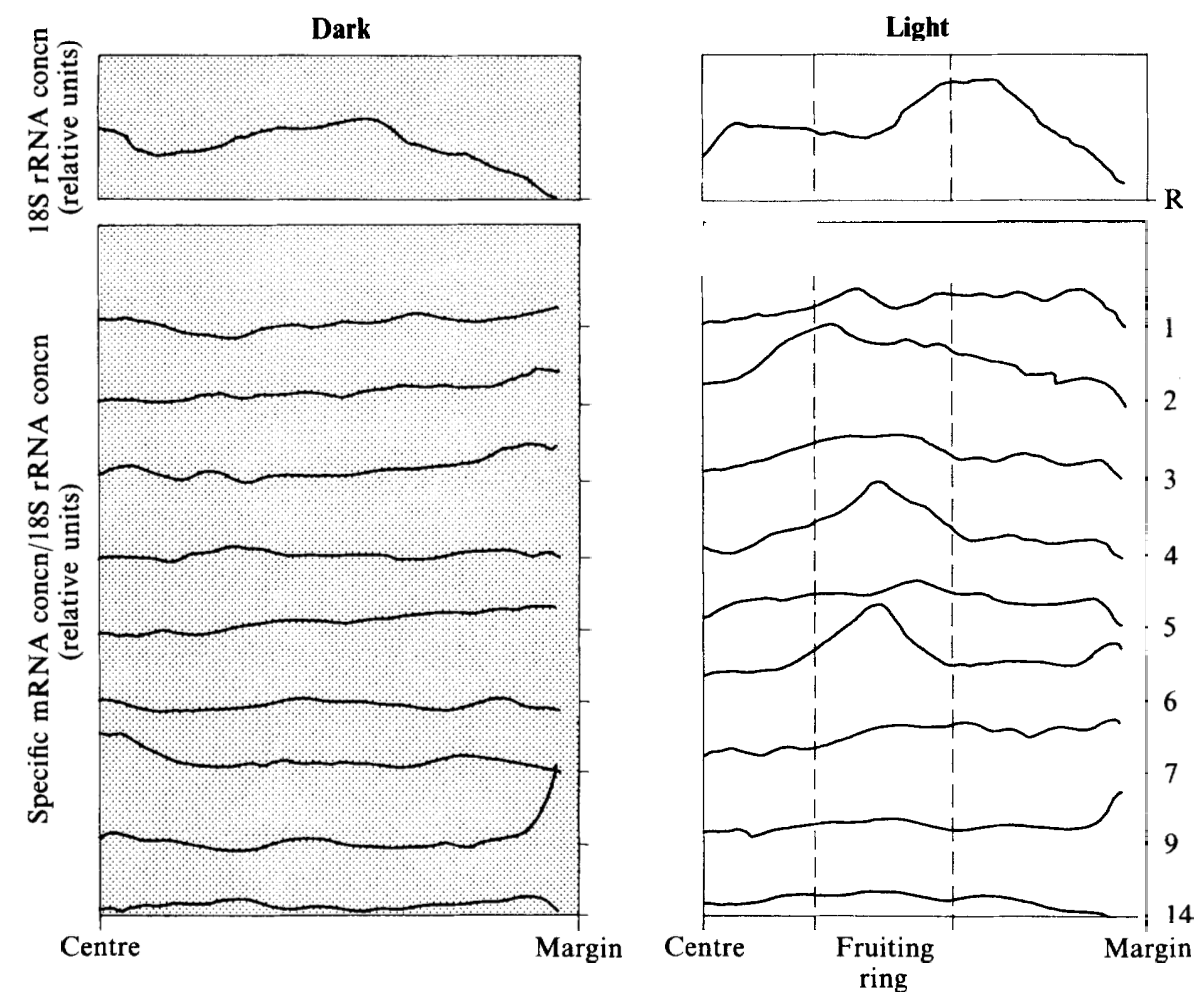

Fig. 3. Relative abundance of mRNAs (mRNA concn/rRNA concn) along radii of colonies as estimated by scanning autoradiographs after hybridizations to cDNA clones followed by rehybridization to an $18 \mathrm{~S}$ rDNA clone (as described in Methods). The numbers of the mRNAs traced are shown to the right. The upper profiles (R) show the distribution of 18S-rRNA in the colonies. The colonies were grown for $7 \mathrm{~d}$ in the dark (left-hand column) or for $5 \mathrm{~d}$ in the dark and then in the light for $2 \mathrm{~d}$ (righthand column).

hybridization, because no signal occurred after RNAase treatment and the signals were confined to specific parts of the colonies.

The estimated amount of RNA in the hybridized sectors of the colonies was $50-100 \mu \mathrm{g}$. From previous measurements on the abundance of the probed mRNAs (Mulder \& Wessels, 1986; Ruiters et al., 1988) we estimate that in the hybridized $30^{\circ}$ colony sectors the more abundant probed mRNAs amounted to 50-100 ng. Because each sector was hybridized to $12.5 \mathrm{ng}$ of probe containing about $2.5 \mathrm{ng}$ of specific insert DNA, this probably resulted in non-excess hybridization conditions for most of the mRNAs and certainly for the 18S rRNA. Consequently, the signals obtained cannot be taken as a measure of the absolute amounts of the various probed RNAs but merely reflect differences in the local abundance of specific RNAs in the colony. Under these conditions the access of the probes to cytoplasmic RNA becomes very critical. Because it is difficult to assess possible differences in wall permeabilization by the wall-lytic enzymes in the different parts of the colony this introduces uncertainty about the significance of the height of the signal. However, we feel that this was not a serious problem in the present hybridizations because the $18 \mathrm{~S}$ rRNA probe hybridized to all parts of the colony.

The detection and localization of dikaryon-specific mRNA by in situ hybridizations gave results in general agreement with those obtained in previous experiments using hybridizations to RNA extracted from concentric rings of colonies (Ruiters et al., 1988; Yli-Mattila et al., 1989). Light simultaneously induced the dikaryon-specific mRNAs and the fruit bodies in a ring (approximately $5 \mathrm{~mm}$ wide) just inside the margin of the colony as present at the moment of transfer to light. However, the in situ colony hybridizations presented here give much more detailed information about this correlation. (i) The mRNAs were not uniformly produced in the 
colony ring but only at locations where fruit-body initials actually formed. (ii) The mRNAs became concentrated in primordia which continued development but disappeared from abortive primordia. This coincided with the general drop in the concentrations of these mRNAs in the ring as measured in extracted RNA (Ruiters et al., 1988). (iii) The developing fruit-body primordia also accumulated rRNA whereas the amount of rRNA in the abortive primordia and in the vegetative mycelium drastically diminished at the same time. Only the vegetative mycelium at the growing edge of the colony maintained a relatively high concentration of rRNA. Apparently, the developing fruit bodies drew on abortive fruit bodies and vegetative mycelium for rRNA. We suspect that this is accomplished through controlled hydrolysis of rRNA and transport of nucleotides to the developing fruit bodies. It was concluded earlier that after depletion of nutrients growth of fruit bodies is accompanied not only by controlled degradation of RNA but also of protein, glycogen and cell-wall components in the vegetative mycelium and abortive primordia to supply the building blocks for the developing fruit bodies (Wessels, 1965; Wessels \& Sietsma, 1979). It now appears that all these processes may also take place in colonies still growing at the margin where external nutrients are available.

The technical assistance of Jan Springer is gratefully acknowledged.

\section{REFERENCES}

AKAM, M. E. (1983). The location of ultrabithorax transcripts in Drosophila tissue sections. EMBO Journal 2, 2075-2084.

Blanc, H., Dujon, J. B., Guerineau, M. \& SlonIMSKI, P. P. (1978). Detection of specific DNA sequences in yeast by colony hybridization. Molecular and General Genetics 161, 311-315.

Cornish, E. C., Pettitt, J. M., Bonig, I. \& Clarke, A. E. (1987). Developmentally controlled expression of a gene associated with self-incompatibility in Nicotiana alata. Nature, London 326, 99-102.

Cox, K. H., Deleon, D. V., Angerer, L. M. \& ANGERER, R. C. (1984). Detection of mRNAs in sea urchin embryos by in situ hybridization using asymmetric RNA probes. Developmental Biology 101, 485-502.

Crowley, P. \& Oliver, S. G. (1987). A microculture hybridization technique for the detection of specific DNA sequences in filamentous fungi. Experimental Mycology 11, 70-73.

De VRIES, O. M. H. \& WeSSels, J. G. H. (1972). Release of protoplasts from Schizophyllum commune by a lytic enzyme preparation from Trichoderma viride. Journal of General Microbiology 73, 13-22.

De Vries, O. M. H. \& Wessels, J. G. H. (1973). Effectiveness of a lytic enzyme preparation from Trichoderma viride in releasing spheroplasts from fungi, particularly basidiomycetes. Antonie van Leeuwenhoek 39, 397-400.

Hafen, E., Levine, M., Garber, R. L. \& Gehring, W. J. (1983). An improved in situ hybridization method for the detection of cellular RNAs in Drosophila tissue sections and its application for localizing transcripts of the antennapedia gene complex. EMBO Journal 2, 617-623.

Hinnen, A., Hicks, J. B. \& FinK, G. R. (1978). Transformation of yeast. Proceedings of the National Academy of Sciences of the United States of America 75, 1929-1933.

Martineau, B. \& Taylor, W. C. (1986). Cell-specific photosynthetic gene expression in maize determined using cell separation techniques and hybridization in situ. Physiologia plantarum 82, 613-618.

MeINkoth, J. \& WAHL, G. (1984). Hybridization of nucleic acids bound to solid supports. Analytical Biochemistry 138, 267-284.

MUlder, G. H. \& Wessels, J. G. H. (1986). Molecular cloning of RNAs differentially expressed in monokaryons and dikaryons of Schizophyllum commune in relation to fruiting. Experimental Mycology 10, 214227.

RAPER, J. R. \& HoFFMAN, R. M. (1974). Schizophyllum commune. In Handbook of Genetics, vol. 1, pp. 597 626. Edited by R. C. King. New York: Plenum.

Ruiters, M. H. J. \& Wessels, J. G. H. (1989). In situ localization of specific mRNAs in developing fruit bodies of the basidiomycete Schizophyllum commune. Experimental Mycology 13 (in the Press).

Ruiters, M. H. J., Sietsma, J. H. \& Wessels, J. G. H. (1988). Expression of dikaryon-specific mRNAs of Schizophyllum commune in relation to incompatibility genes, light, and fruiting. Experimental Mycology 12, 60-69.

SCHMELZER, E., JAHNEN, W. \& HAHLBROCK, K. (1988). In situ localization of light-induced chalcone synthetase mRNA, chalcone synthase, and flavonoid end products in epidermal cells of parsley leaves. Proceedings of the National Academy of Sciences of the United States of America 85, 2989-2993.

Smith, A. G., Hinchee, M. \& Horsch, R. (1987). Cell and tissue specific expression localized by in situ RNA hybridization in floral tissues. Plant Molecular Biology Reporter 5, 237-241.

SonNenberg, A. S. M. \& Wessels, J. G. H. (1987). Heterokaryon formation in the basidiomycete Schizophyllum commune by electrofusion of protoplasts. Theoretical and Applied Genetics 74, 654-658.

Stohl, L. L. \& Lambowitz, A. M. (1983). A colonyfilter-hybridization procedure for the filamentous fungus Neurospora crassa. Analytical Biochemistry 134, 82-85.

WeSSELS, J. G. H. (1965). Morphogenesis and bio- 
chemical processes in Schizophyllum commune. Wentia 13, 1-113.

Wessels, J. G. H. (1987). Mating-type genes and the control of expression of fruiting genes in basidiomycetes. Antonie van Leeuwenhoek 53, 307-317.

Wessels, J. G. H. \& Sietsma, J. H. (1979). Wall structure and growth in Schizophyllum commune. In Fungal Walls and Hyphal Growth (British Mycological Society Symposium 2), pp. 27-48. Edited by J. H. Burnett \& A. P. J. Trinci. Cambridge: Cambridge University Press.

Wessels, J. G. H., Mulder, G. H. \& Springer, J.
(1987). Expression of dikaryon-specific mRNAs of Schizophyllum commune in relation to environmental conditions and fruiting. Journal of General Microbiology 133, 2557-2561.

Yli-Mattila, T., Ruiters, M. H. J. \& Wessels, J. G. H. (1989). Photoregulation of dikaryon specific mRNAs and proteins by UV-A light in Schizophyllum commune. Current Microbiology 19 (in the Press).

YU, S.-M. \& GoRovsKy, M. A. (1986). In situ dotblots: quantitation of mRNA in intact cells. Nucleic Acids Research 14, 7597-7615. 